\title{
Pembuatan Aplikasi Panduan Gizi Seimbang Berbasis Android Dengan Menggunakan Metode Backward Chaining
}

Gilang Aditya Pamungkas, R. Rizal Isnanto, Kurniawan Teguh Martono. Program Studi Sistem Komputer Fakultas Teknik Universitas Diponegoro Jalan Prof. Sudharto, Tembalang, Semarang, Indonesia

\begin{abstract}
Abstrak-- Seiring dengan perkembangan jaman, tuntutan pekerjaan yang sangat banyak akan menyita waktu serta tenaga sehingga banyak manusia yang mengganggap suatu hal yang seharusnya penting menjadi bukan prioritas utama lagi salah satunya adalah makan. Banyak yang tidak memperhatikan tentang bagaimana makanan tersebut dapat berpengaruh kepada tubuh. Karena kelalaiannya seringkali jumlah kalori yang masuk dalam tubuh berlebih berakibat buruk bagi kesehatan tubuh pada umumnya menimbulkan penyakit obesitas atau kelebihan berat badan yang dapat memicu penyakit lainnya seperti Diabetes, Jantung Koroner, Hipertensi dan lain-lain.

Salah satu metode untuk menghitung jumlah kalori sehari-hari yang dibutuhkan oleh tubuh dalam satuan kilokalori menggunakan rumus Harris Benedict. Jumlah asupan kilokalori harian yang direkomendasikan adalah untuk menjaga berat badan agar tetap normal. Fitur kalkulator kalori untuk menghitung kalori makanan. Aplikasi ini dibangun dengan menggunakan metode Backward Chaining sebagai mesin inferensinya.

Aplikasi Panduan Gizi Seimbang ini diuji fungsinya menggunakan metode Whitebox dimana hasil pengujian bahwa fungsi berjalan dengan baik dan pengujian basis pengetahuan aplikasi dilakukan langsung kepada ahli gizi dengan hasil bahwa aplikasi memiliki keakuratan yang baik sesuai dengan hasil analisa pakar. Hasil dari penelitian dan pengujian ini menunjukkan bahwa aplikasi Panduan Gizi Seimbang dapat menghitung jumlah kalori yang harus dikonsumsi serta menilai kalori makanan sesuai dengan tujuan dibuatnya aplikasi ini.
\end{abstract}

Kata Kunci : Android, Rumus Harris Benedict, Kalkulator Kalori, Backward Chaining

\section{PENDAHULUAN}

$\mathrm{S}_{\mathrm{s}}^{\mathrm{e}}$ eiring dengan perkembangan zaman, tuntutan pekerjaan $S_{\text {yang sangat banyak akan menyita waktu serta tenaga }}$ sehingga banyak manusia yang mengganggap suatu hal yang seharusnya penting menjadi bukan prioritas utama lagi salah satunya adalah makan. Banyak yang tidak memperhatikan tentang bagaimana makanan tersebut dapat berpengaruh bagi tubuh. Salah satu metode untuk mengukur jumlah kalori yang dikonsumsi adalah metode Harris Benedict yang ditemukan oleh James Arthur Harris dan Francis Gano Benedict pada tahun $1918^{[3]}$.

Melalui Penelitian ini, akan dibangun sebuah aplikasi yang bertujuan sebagai alternatif dalam mengetahui tingkat kalori yang dibutuhkan tubuh menggunakan metode Harris Benedict, mengetahui indeks masa tubuh apakah normal atau tidak serta menggunakan backward chaining dalam teknik penalaran yang digunakan.

Untuk menghindari pembahasan yang meluas, maka dalam tugas akhir ini ditetapkan batasan-batasan masalah sebagai berikut:

1. Aplikasi disimulasikan pada sistem operasi Android versi 4.3 Jelly Bean dengan ukuran layar 5 inci.

2. Aplikasi ini menggunakan metode Backward chaining sebagai teknik penalaran.

\section{LANDASAN TEORI}

\section{A. Gizi Seimbang}

Gizi Seimbang adalah susunan makanan sehari-hari yang mengandung zat-zat gizi dalam jenis dan jumlah yang sesuai dengan kebutuhan tubuh. Pedoman Umum Gizi Seimbang (PUGS) adalah pedoman dasar tentang gizi seimbang yang disusun sebagai penuntun pada perilaku konsumsi makanan di masyarakat secara baik dan benar ${ }^{[9]}$. Bahan makanan Dikelompokkan menjadi tiga yaitu sumber energi, sumber protein, dan sumber zat pengatur. PUGS diilustrasikan pada Gambar 1.
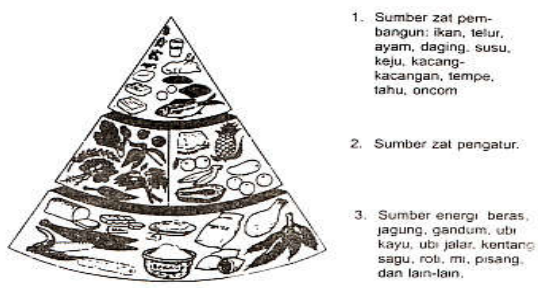

Gambar 1. Pedoman Umum Gizi Seimbang (PUGS) dalam bentuk kerucut

PUGS menganjurkan agar 60-75\% kebutuhan energi diperoleh dari karbohidrat, $10-15 \%$ dari protein, dan $10-25 \%$ dari lemak.

\section{B. Metode Harris Benedict}

Komponen utama yang menentukan kebutuhan energi seseorang adalah Angka Metabolisme Basal (AMB) dan aktivitas fisik. Angka metabolisme basal adalah kebutuhan energi minimal yang dibutuhkan tubuh untuk menjalankan proses tubuh ${ }^{[3]}$. Angka metabolisme basal dinyatakan dalam satuan kilokalori (kkal). Angka metabolisme basal pada penelitian ini menggunakan rumus Harris-Benedict yang ditunjukkan pada Persamaan 1 dan 2 berikut : 
AMB untuk Laki-laki=

$66+(13,7 \times \mathrm{BB})+(5 \times \mathrm{TB})-(6,8 \times \mathrm{U})$

atau :

AMB untuk Perempuan=

$655+(9,6 \times \mathrm{BB})+(1,8 \times \mathrm{TB})-(4,7 \times \mathrm{U})$

dari :

$\mathrm{BB}=$ Berat Badan $(\mathrm{kg})$

$\mathrm{TB}=$ Tinggi Badan $(\mathrm{cm})$

$\mathrm{U}=$ Umur dalam tahun

Setelah nilai AMB diketahui, langkah selanjutnya adalah menghitung aktivitas fisik. Untuk menghitungnya dapat dilihat pada Tabel $1^{[9]}$.

Tabel 1 Kebutuhan energi menurut aktivitas

\begin{tabular}{|c|c|c|}
\hline \multirow{2}{*}{ Aktivitas } & \multicolumn{2}{|c|}{ Gender } \\
\cline { 2 - 3 } & Laki-laki & Perempuan \\
\hline Sangat ringan & 1,30 & 1,30 \\
\hline Ringan & 1,65 & 1,55 \\
\hline Sedang & 1,76 & 1,70 \\
\hline Berat & 2,10 & 2,00 \\
\hline
\end{tabular}

Setelah mendapatkan nilai aktivitas fisik yang sesuai dengan jenis aktivitasnya, kalikan nilai tersebut dengan AMB yang ditunjukkan pada Persamaan 3.

Kebutuhan energi=nilai aktivitas fisik x AMB

Nilai kebutuhan energi untuk AMB diperhitungkan menurut berat badan normal atau ideal dengan menggunakan Indeks Masa Tubuh (IMT) seperti pada Persamaan 4.

$$
\mathrm{IMT}=\frac{\text { Berat Badan }(\mathrm{kg})}{\text { Tinggi Badan }(\mathrm{m})^{2}}
$$

Nilai IMT ini digunakan sebagai ambang batas kondisi tubuh seperti pada Tabel $2^{[10]}$.

Tabel 2 Kategori batas ambang IMT

\begin{tabular}{|c|l|c|}
\hline Kondisi Tubuh & \multicolumn{1}{|c|}{ Kategori } & $\begin{array}{c}\text { Batas } \\
\text { Ambang }\end{array}$ \\
\hline \multirow{2}{*}{ Kurus } & $\begin{array}{l}\text { Kekurangan berat } \\
\text { badan tingkat berat }\end{array}$ & $<17,0$ \\
\cline { 2 - 3 } & $\begin{array}{l}\text { Kekurangan berat } \\
\text { badan tingkat ringan }\end{array}$ & $17,0-18,5$ \\
\hline Normal & $\begin{array}{l}\text { Kelebihan berat badan } \\
\text { tingkat ringan }\end{array}$ & $>25,0-27,0$ \\
\cline { 2 - 3 } Gemuk & $\begin{array}{l}\text { Kelebihan berat badan } \\
\text { tingkat berat }\end{array}$ & $>27,0$ \\
\hline
\end{tabular}

Bila nilai IMT kurang dari normal maka berat badan kurang dari ideal untuk itu kebutuhan energinya ditambah sebanyak 500 kilokalori. Jika nilai IMT lebih dari normal maka berat badan lebih dari ideal sehingga kebutuhan energinya dikurangi sebanyak 500 kilokalori.

\section{Android}

Android adalah salah satu sistem operasi pada perangkat bergerak. Menurut Suprianto ${ }^{[7]}$ Android mengadopsi sistem operasi Linux, namun telah dimodifikasi. Android diambil alih oleh Google pada tahun 2005 dari Android. Inc sebagai bagian dari strategi untuk mengisi pasar sistem operasi bergerak (mobile operating system). Android Studio adalah sebuah IDE untuk pengembangan aplikasi di platform Android yang dirilis oleh Google pada akhir tahun 2014.

D. Sistem Pakar dan Metode Backward Chaining
Sistem pakar adalah suatu program komputer yang memperlihatkan derajat keahlian dalam pemecahan masalah dibidang tertentu sebanding dengan seorang pakar ${ }^{[8]}$. Sistem pakar menggunakan mesin inferensi untuk menemukan solusi dari sebuah permasalahan berdasarkan informasi yang diperolehnya. Mesin inferensi sendiri menurut Wawan ${ }^{[10]}$ adalah bagian yang bertindak sebagai pencari solusi dari suatu permasalahan berdasar pada kaidah-kaidah yang ada dalam basis pengetahuan sistem pakar.

Ada dua metode dalam mesin inferensi yaitu metode runut maju atau forward chaining, dan metode runut balik atau backward chaining. Metode runut balik memulai proses pencarian dari tujuan, yaitu kesimpulan yang menjadi solusi permasalahan yang dihadapi. Strategi ini disebut juga goaldriven. Proses runut balik ini diilustrasikan pada Gambar 2.

\begin{tabular}{lll} 
FAKTA & ATURAN & $\longleftarrow$ TUJUAN \\
IMT $<17,0$ & JKA IMT $<17,0$ & KONDISI = SANGAT \\
& MAKA KONDISI $=$ & KURUS \\
& SANGAT KURUS & \\
\hline
\end{tabular}

Gambar 2. Ilustrasi Runut Balik

\section{E. Model Proses Perangkat Lunak Waterfall}

Model proses perangkat lunak merupakan representasi abstrak dari proses perangkat lunak. Berkat penurunan dari satu fase ke fase lainnya, model ini dikenal sebagai 'model air terjun, ${ }^{[2]}$. Model ini diilustrasikan pada Gambar 3.

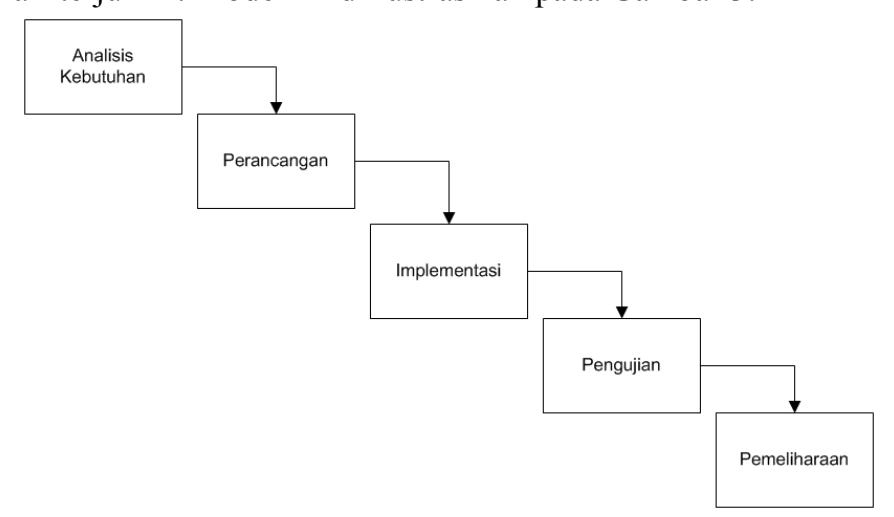

Gambar 3. Model Waterfall

Menurut Rosa dan Shalahudin ${ }^{[1]}$ tahap-tahap utama dari model ini memetakan kegiatan-kegiatan pengembangan dasar, yaitu :

a. Analisis kebutuhan

Proses pengumpulan kebutuhan dilakukan secara intensif untuk menspesifikasikan kebutuhan agar dapat dipahami perangkat lunak seperti apa yang dibutuhkan oleh pengguna.

b. Perancangan atau desain

Proses perancangan membagi persyaratan dalam sistem perangkat lunak. Kegiatan ini menentukan arsitektur sistem secara keseluruhan seperti struktur data, representasi antarmuka.

c. Implementasi

Pada tahap ini, perancangan perangkat lunak direalisasikan sebagai serangkaian program atau unit program. Hasil dari tahap ini adalah program komputer sesuai dengan desain yang telah dibuat pada tahap perancangan. 


\section{d. Pengujian sistem}

Pengujian fokus pada perangkat lunak dari segi logis dan fungsional, memastikan bahwa semua bagian sudah diuji untuk meminimalisir kesalahan dan memastikan keluaran yang dihasilkan sesuai dengan yang diinginkan.

e. Pemeliharaan

Pada umumnya ini merupakan fase siklus hidup yang paling lama. Tidak menutup kemungkinan bahwa harus perangkat lunak mengalami perubahan yang disebabkan karena kesalahan yang muncul dan tidak terdeteksi pada saat pengujian atau perangkat lunak harus beradaptasi dengan lingkungan baru. Tahap ini dapat mengulangi proses pengembangan mulai dari analisis kebutuhan untuk perubahan perangkat lunak yang sudah ada tapi tidak untuk membuat perangkat lunak baru.

\section{PERANCANGAN SISTEM}

Pada bab ini akan membahas langkah-langkah perancangan aplikasi sesuai dengan tahapan yang ada pada metode waterfall.

\section{A. Definisi persyaratan}

Aplikasi ini dapat digunakan oleh semua kalangan dan jenis kelamin kecuali untuk ibu hamil dan dalam kondisi sakit, dengan harapan dapat mempermudah manusia dalam memahami tentang makanan yang dikonsumsinya seharihari. Berdasarkan konsep aplikasi yang telah ditentukan, maka dibuatlah deskripsi konsep aplikasi panduan gizi seimbang seperti pada Tabel 3.

Tabel 3. Tabel deskripsi konsep aplikasi

\begin{tabular}{|l|c|l|}
\hline Judul & $:$ & Panduan Gizi Seimbang \\
\hline Pengguna & $:$ & $\begin{array}{l}\text { Semua Kalangan kecuali ibu } \\
\text { hamil dan dalam kondisi } \\
\text { sakit }\end{array}$ \\
\hline Jenis Aplikasi & $:$ & Kesehatan \\
\hline Basis & $:$ & Android \\
\hline $\begin{array}{l}\text { Spesifikasi Minimum } \\
\text { Aplikasi }\end{array}$ & $:$ & $\begin{array}{l}\text { Spesifikasi } \\
\text { aplikasi adalah perangkat } \\
\text { yang memiliki sistem operasi } \\
\text { Android versi 2.3.3 } \\
\text { (GingerBread) }\end{array}$ \\
\hline Perangkat & $:$ & $\begin{array}{l}\text { Smartphone } \\
\text { Android }\end{array}$ \\
\hline
\end{tabular}

\section{B. Desain Sistem dan Perangkat Lunak}

Terdapat tiga tahap dalam perancangan aplikasi, yaitu :

1. Perancangan sistem dengan menggambarkan sistem secara terstruktur terhadap sistem dan alur datanya.

2. Perancangan antarmuka dengan menggambarkan desain tampilan aplikasi yang kemudian dijadikan acuan dalam pembuatan aplikasi.

3. Perancangan basis pengetahuan dengan merancangan basis pengetahuan serta bagaimana cara aplikasi mengambil kesimpulan dari fakta-fakta yang tersedia.

\section{Perancangan Sistem}

Pada tahap ini akan digambarkan secara umum sistem yang akan dibuat dengan menggunakan beberapa diagram alir yang memiliki fungsi-fungsi yang berbeda dalam menggambarkan suatu sistem. Gambar 4. merupakan diagram Alir pada halaman awal aplikasi.

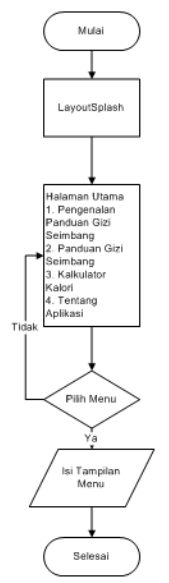

Gambar 4. Diagram Alir tampilan awal aplikasi

Tampilan aplikasi untuk menu Pengenalan Gizi Seimbang diilustrasikan dengan diagram Alir yang ditunjukkan pada Gambar 5.

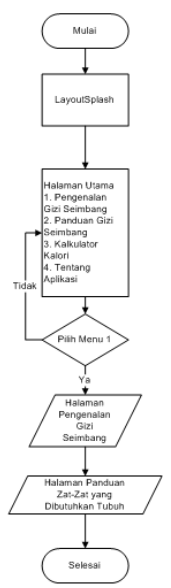

Gambar 5. Diagram Alir tampilan pengenalan panduan gizi seimbang

Diagram alir aplikasi untuk menu Panduan Gizi Seimbang ditunjukkan pada Gambar 6.

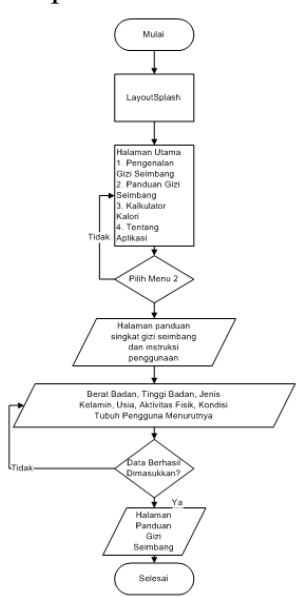

Gambar 6. Diagram Alir tampilan panduan gizi seimbang

Diagram Alir aplikasi untuk menu Kalkulator Kalori ditunjukkan pada Gambar 7. 


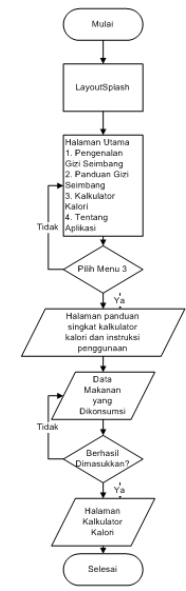

Gambar 7. Diagram Alir tampilan kalkulator kalori

Diagram Alir aplikasi untuk menu Tentang Aplikasi ditunjukkan pada Gambar 8.

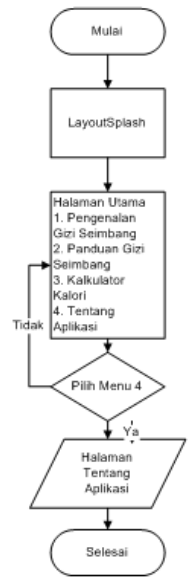

Gambar 8. Diagram Alir tampilan tentang aplikasi

\section{Perancangan Basis Pengetahuan}

Pada tahap perancangan basis pengetahuan ini yang dilakukan adalah membuat diagram alir dari aturan aplikasi. Mesin inferensi yang akan digunakan pada aplikasi adalah runut balik atau backward chaining. Ilustrasi sederhana mengenai untuk menentukan kondisi tubuh sangat kurus ditunjukkan pada Gambar 9.

$\begin{array}{lll}\text { FAKTA } & \text { ATURAN } & \text { HASIL } \\ \text { IMT }<17,0 & \text { JIKA IMT }<17,0 & \text { KONDISI = SANGAT } \\ & \text { MAKA KONDISI }= & \text { KURUS } \\ & \text { SANGAT KURUS } & \\ & \end{array}$

Gambar 9. Menentukan Kondisi Tubuh Sangat Kurus

Kondisi tubuh sangat kurus didapatkan apabila IMT pengguna menggunakan Persamaan 4 menunjukkan angka dibawah 17,0. Ilustrasi untuk menentukan kondisi tubuh pengguna kurus ditunjukkan pada Gambar 10.

\begin{tabular}{lll} 
FAKTA & ATURAN & HASIL \\
IMT 17,0-18,5 & JIKA IMT 17,0-18,5 & KONDISI = KURUS \\
& MAKA KONDISI = \\
& KURUS \\
\hline
\end{tabular}

Gambar 10. Menentukan Kondisi Tubuh Kurus

Kondisi tubuh kurus ditentukan dari nilai IMT pengguna menunjukkan angka antara 17,0 sampai dengan 18,5 menggunakan Persamaan 4. Berikut merupakan ilustrasi dimana sistem menentukan kondisi tubuh pengguna adalah normal ditunjukkan pada Gambar 11.

$\begin{array}{lll}\text { FAKTA } & \text { ATURAN } & \text { HASIL } \\ \text { IMT }>18,5-25,0 & \text { JIKA IMT }>18,5-25,0 & \text { KONDISI = NORMAL } \\ & \text { MAKA KONDISI }= & \\ & \text { NORMAL }\end{array}$

Gambar 11. Menentukan Kondisi Tubuh Normal

Kondisi tubuh normal ditentukan dari nilai IMT pengguna menunjukkan angka lebih besar dari 18,5 sampai dengan 25,0 menggunakan Persamaan 4. Berikut merupakan ilustrasi dimana sistem menentukan kondisi tubuh pengguna adalah gemuk ditunjukkan pada Gambar 12.

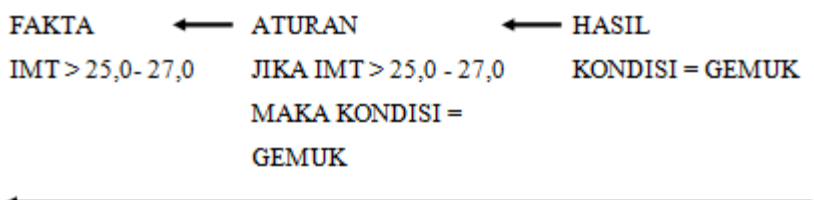

Gambar 12. Menentukan Kondisi Tubuh Gemuk

Kondisi tubuh gemuk ditentukan dari nilai IMT pengguna menunjukkan angka lebih besar dari 25,0 sampai dengan 27,0 menggunakan Persamaan 4. Berikut merupakan ilustrasi dimana sistem menentukan kondisi tubuh pengguna adalah sangat gemuk ditunjukkan pada Gambar 13.

$\begin{array}{lll}\text { FAKTA } & \longleftarrow \text { ATURAN } & \longleftarrow \text { HASIL } \\ \text { IMT }>27,0 & \text { JIKA IMT }>27,0 & \text { KONDISI = SANGAT } \\ & \text { MAKA KONDISI }= & \text { GEMUK } \\ & \text { SANGAT GEMUK } & \end{array}$

Gambar 14. Menentukan Kondisi Tubuh Sangat Gemuk

Kondisi tubuh gemuk ditentukan dari nilai IMT pengguna menunjukkan angka lebih besar dari 27,0 menggunakan Persamaan 4.

\section{Perancangan Desain Antarmuka}

Pada tahap perancangan desain antarmuka ini yang dilakukan adalah membuat Layout dan flowchart view dari aplikasi yang akan dibuat. Berikut ini merupakan rancangan Layout Home yang digambarkan pada Gambar 15.

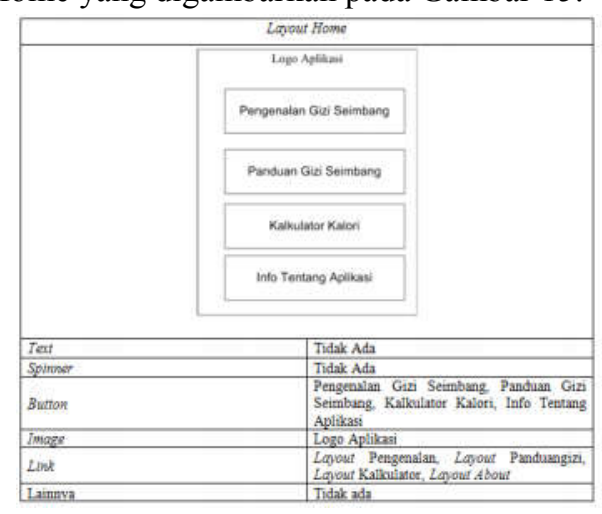

Gambar 15. Rancangan Layout Home

Rancangan tampilan yang kedua merupakan gambaran tampilan menu utama yang terdapat pada aplikasi ini, Menumenu itu sendiri akan menghubungkan ke Layout terkait jika pengguna memilihnya. Berikut ini merupakan rancangan Layout Pengenalan yang digambarkan pada Gambar 16. 


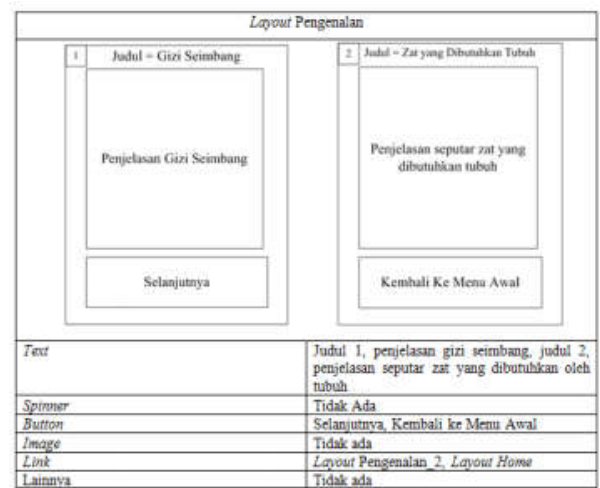

Gambar 16. Rancangan Layout Pengenalan

Layout Pengenalan terbagi menjadi dua tampilan. Tampilan pertama yaitu Pengenalan_1 menampilkan penjelasan singkat mengenai gizi seimbang. Pada tampilan kedua yaitu Pengenalan_2 memberikan penjelasan singkat mengenai zat-zat yang dibutuhkan oleh tubuh manusia. Berikut ini merupakan rancangan Layout Panduangizi yang digambarkan pada Gambar 17.

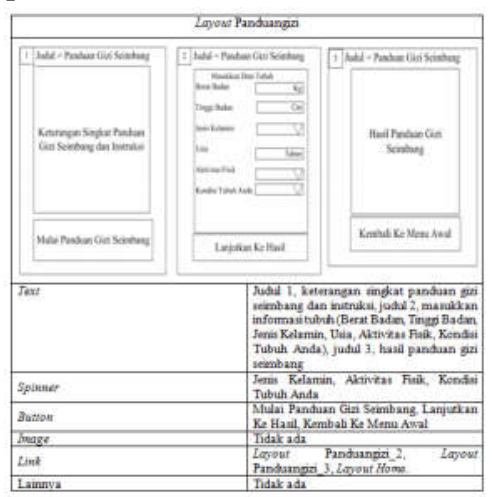

Gambar 17. Rancangan Layout Panduangizi

Layout Panduangizi terbagi menjadi tiga tampilan. Tampilan pertama yaitu panduangizi_1 menampilkan informasi tentang panduan gizi seimbang serta bagaimana cara menggunakannya. Pada tampilan kedua yaitu panduangizi_2 menampilkan enam masukkan yang akan diproses antara lain berat badan, tinggi badan, jenis kelamin, usia, aktivitas fisik yang dijalani, serta kondisi tubuh menurut pengguna. Dan tampilan ketiga yaitu panduangizi_3 menampilkan hasil panduan gizi seimbang yang berasal dari masukkan pada panduangizi_2 yang telah diproses. Berikut ini merupakan rancangan Layout Kalkulator yang digambarkan pada Gambar 18.

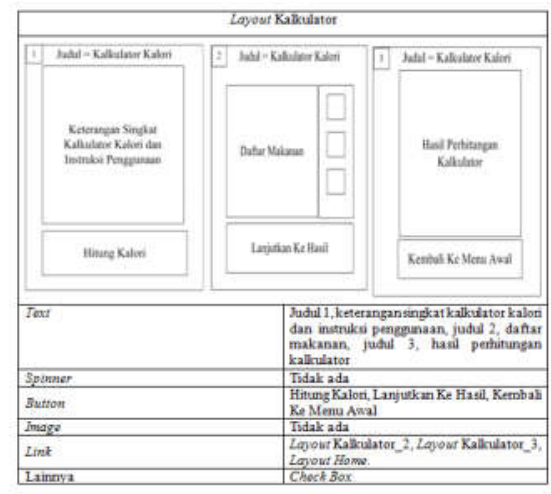

Gambar 18. Rancangan Layout Kalkulator

Layout Kalkulator terbagi menjadi tiga tampilan. Tampilan pertama yaitu Kalkulator_1 menampilkan keterangan singkat tentang kalkulator kalori dan cara menggunakannya. Pada tampilan kedua yaitu Kalkulator_2 menampilkan daftar makanan yang pengguna bisa memilihnya. Pada tampilan terakhir yaitu Kalkulator_3 menampilkan hasil perhitungan dari data yang telah dimasukkan sebelumnya.

\section{IMPLEMENTASI DAN PENGUJIAN SISTEM}

Dalam Bab ini akan membahas tahap implementasi dan pengujian sistem dari aplikasi Panduan Gizi Seimbang. Pembuatan aplikasi ini mewujudkan hasil dari perancangan yang terdapat pada Bab III, sehingga dihasilkan aplikasi yang bekerja sesuai dengan fungsinya.

\section{A. Tahap Implementasi}

Pembuatan aplikasi dilakukan secara terurut berdasarkan kebutuhan dari sistem itu sendiri, oleh karena itu pada pembuatan aplikasi ini yang pertama dibuat adalah tampilan aplikasi. Ketika aplikasi ini dijalankan, halaman pertama yang akan muncul adalah layout Splash yang ditunjukkan pada Gambar 19. Layout Splash ini terdiri dari gambar logo aplikasi dan nama aplikasi dan ProgressBar.

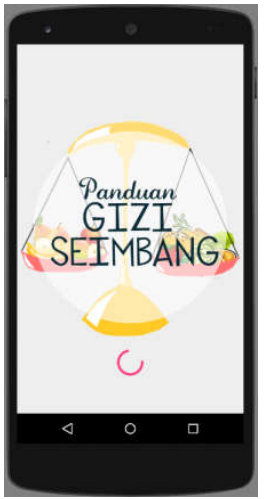

Gambar 19. Tampilan Layout Splash

Halaman ini akan tampil selama 2 detik setelah itu secara otomatis akan menuju ke halaman berikutnya yaitu Layout Home. Gambar 20 menunjukkan tampilan dari layout Home.

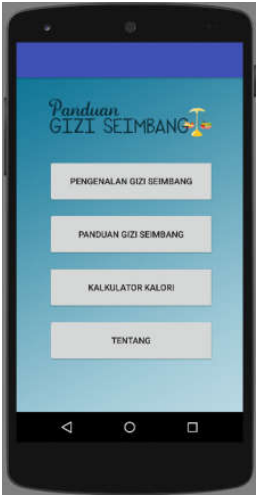

Gambar 20. Tampilan Layout Home

Tampilan layout Home terdiri dari gambar logo aplikasi serta Tombol menu utama yang dapat dipilih antara lain menu Pengenalan Panduan Gizi Seimbang, menu Panduan Gizi Seimbang, menu Kalkulator Kalori, menu Tentang. Apabila pengguna memilih menu Pengenalan Panduan Gizi Seimbang maka halaman selanjutnya yang akan ditampilkan adalah layout Pengenalan_1 seperti yang ditunjukkan pada Gambar 21. 


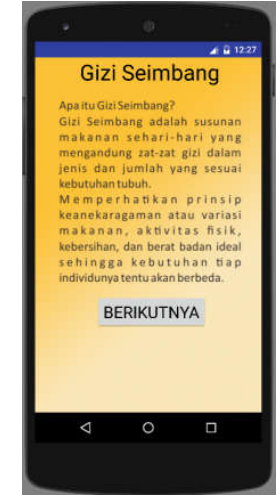

Gambar 21. Tampilan Layout Pengenalan_1

Pada halaman ini akan ditampilkan 2 teks yaitu judul halaman dan penjelasan singkat mengenai gizi seimbang serta satu buah tombol yaitu tombol Berikutnya. Apabila pengguna memilih tombol Berikutnya pada halaman layout Pengenalan_1 maka halaman selanjutnya yang akan tampil adalah layout Pengenalan_2 yang ditunjukkan pada Gambar 22.

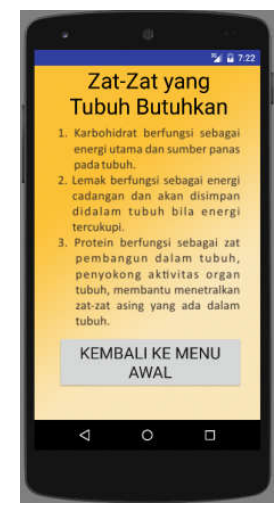

Gambar 22. Tampilan Layout Pengenalan_2

Pada halaman ini akan ditampilkan 2 teks yaitu judul dan penjelasan singkat mengenai zat-zat yang dibutuhkan oleh tubuh serta satu tombol Kembali ke menu awal yang akan mengarahkan pengguna kembali ke layout Home. Bila pengguna memilih menu Panduan Gizi Seimbang maka halaman yang berikutnya akan ditampilkan adalah layout Panduangizi_1 yang ditunjukkan pada Gambar 23.
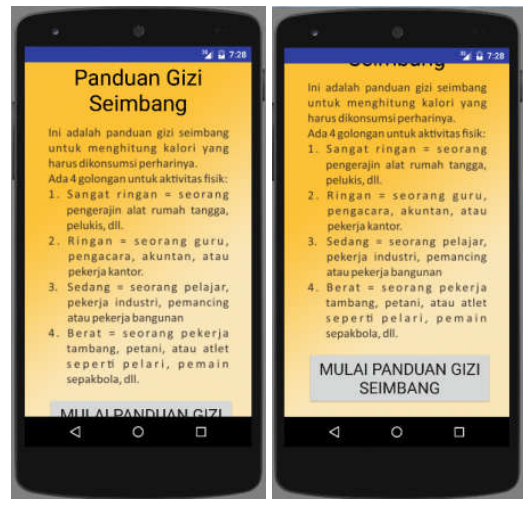

Gambar 23. Tampilan Layout Panduangizi_1

Halaman ini akan menampilkan 2 teks yaitu judul menu serta instruksi singkat penggunaan aplikasi untuk menu Panduan Gizi Seimbang serta satu tombol Mulai Panduan Gizi Seimbang yang akan mengarahkan pengguna ke layout Panduangizi_2. Setelah pengguna memilih maka akan tampil layout Panduangizi_2 seperti pada Gambar 24.

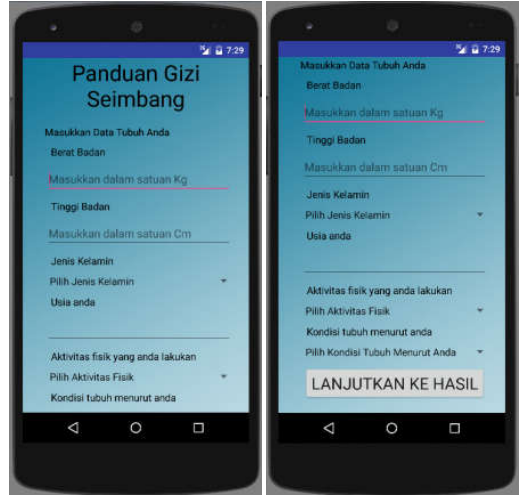

Gambar 24. Tampilan layout Panduangizi_2

Apabila pengguna selesai mengisi form pada layout Panduangizi_2 dan menekan tombol Lanjutkan ke hasil maka akan melanjutkan ke halaman berikutnya yaitu layout Panduangizi_3 seperti yang ditunjukkan pada Gambar 25.

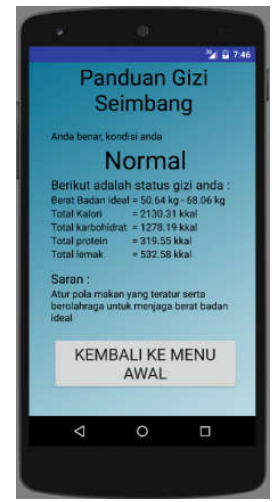

Gambar 25. Tampilan layout Panduangizi_3

Pada layout Home bila pengguna memilih menu Kalkulator Kalori maka akan melanjutkan ke halaman berikutnya yaitu layout Kalkulator_1 seperti yang ditunjukkan pada Gambar 26.

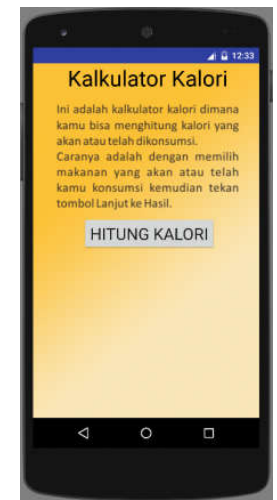

Gambar 26. Tampilan layout Kalkulator_1

Pada halaman ini ditampilkan teks berupa judul menu dan instruksi penggunaan kalkulator kalori serta tombol Hitung Kalori yang akan mengarahkan pengguna menuju ke halaman berikutnya yaitu layout Kalkulator_2 seperti pada Gambar 27. 


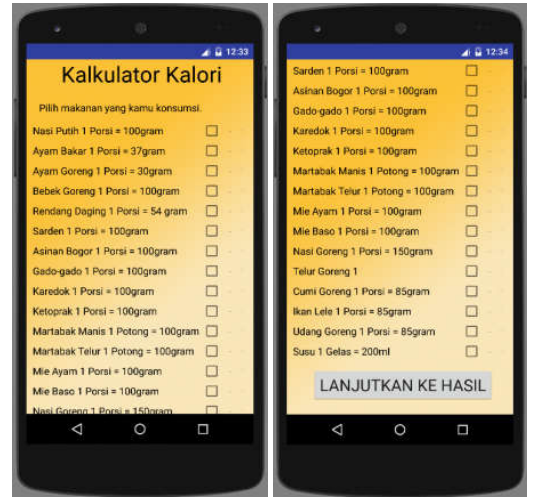

Gambar 27. Tampilan layout Kalkulator_2

Pada halaman ini akan ditampilkan teks berupa judul menu dan daftar makanan serta checkbox untuk pengguna memilih makanan untuk dihitung jumlah kalori yang terkandung didalamnya dan spinner untuk porsi makanan tersebut. Apabila pengguna telah selesai mengisi daftar makanan serta menekan tombol Lanjutkan Ke Hasil maka halaman yang akan tampil berikutnya adalah layout Kalkulator_3 seperti yang ditunjukkan pada Gambar 28.

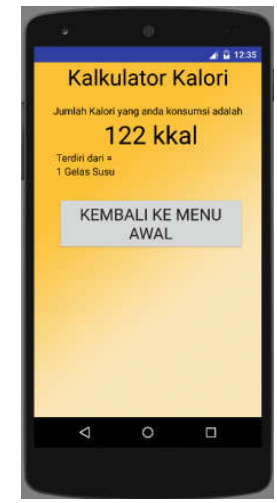

Gambar 28. Tampilan layout Kalkulator_3

\section{B. Tahap Pengujian WhiteBox}

Tahap pengujian sistem merupakan tahapan untuk mencari kesalahan yang terdapat pada aplikasi serta untuk memastikan bahwa aplikasi siap untuk digunakan. Pengujian ini dilakukan untuk menguji bahwa setiap fungsi yang ada pada aplikasi dapat berjalan dengan baik. Pengujian aplikasi Panduan Gizi Seimbang menggunakan metode white box, dimana setiap fungsi yang ada akan diuji secara rinci jalurjalur logika yang ada. Metode pengujiannya menggunakan Struktur Kontrol Program untuk memperoleh kasus uji. Pengujian akan dilakukan untuk masing-masing jalur, cabang, dan perintah.

Pada menu Pengenalan Gizi Seimbang, proses pertama yang dilakukan setelah menu dipilih adalah membuka layout pengenalan1 yang berisi penjelasan seputar gizi seimbang. Kemudian pengguna dapat memlih tombol Berikutnya yang akan menampilkan layout pengenalan2 yang berisi penjelasan tentang zat yang dibutuhkan oleh tubuh. Pada halaman ini pengguna dapat memilih tombol Kembali ke menu awal untuk kembali ke Halaman Beranda (layout Home). Pada Gambar 29 ditunjukkan Flowgraph dari proses pengenalan gizi seimbang dan zat yang dibutuhkan oleh tubuh.

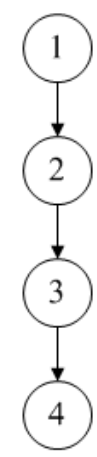

Gambar 29. Flowgraph proses penjelasan pengenalan panduan gizi seimbang dan zat yang dibutuhkan oleh tubuh

Dari Flowgraph pada Gambar 29 didapatkan nilai kompleksitas cyclomatic $\mathrm{V}(\mathrm{G})=\mathrm{E}-\mathrm{N}+2$ atau $\mathrm{V}(\mathrm{G})=\mathrm{P}+1$, dimana $\mathrm{E}$ merupakan jumlah Edge, $\mathrm{N}$ merupakan jumlah Node, sedangkan $\mathrm{P}$ merupakan jumlah cabang, sehingga $\mathrm{V}(\mathrm{G})=0+1=1$. Kemudian didapatkan jalur proses seperti pada Tabel 4.

Tabel 4 Jalur proses pengenalan panduan gizi seimbang dan zat yang dibutuhkan tubuh

\begin{tabular}{|c|c|l|}
\hline Jalur & Tahapan & \multicolumn{1}{|c|}{ Keterangan } \\
\hline 1 & $1-2-3-4$ & $\begin{array}{l}\text { Berhasil membuka halaman } \\
\text { pengenalan panduan gizi seimbang } \\
\text { dan zat yang dibutuhkan tubuh }\end{array}$ \\
\hline
\end{tabular}

Pengujian selanjutnya yaitu pada menu Panduan Gizi

Seimbang. Setelah pengguna memilih menu tersebut, proses pertama yang dilakukan setelah menu dipilih adalah membuka layout panduan1 yang berisi insturksi penggunaan panduan gizi seimbang. Setelah pengguna memilih tombol Mulai Panduan Gizi Seimbang yang akan menampilkan layout panduan2 yang berisi form data diri pengguna. Setelah itu pengguna dapat memilih tombol Lanjutkan ke hasil yang akan menampilkan layout panduan3 yang berisi hasil panduan gizi seimbang. Pada halaman ini pengguna dapat memilih tombol Kembali ke menu awal untuk kembali ke Halaman Beranda (layout Home). Pada Gambar 30 ditunjukkan Flowgraph dari proses panduan gizi seimbang. 


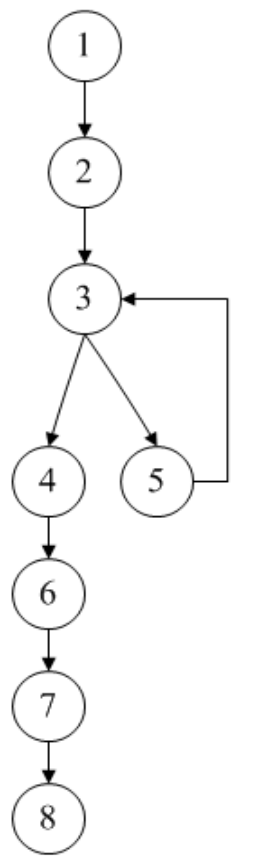

Gambar 30. Flowgraph proses panduan gizi seimbang

Dari Flowgraph pada Gambar 30 didapatkan nilai kompleksitas cyclomatic $\mathrm{V}(\mathrm{G})=\mathrm{E}-\mathrm{N}+2$ atau $\mathrm{V}(\mathrm{G})=\mathrm{P}+1$, dimana $\mathrm{E}$ merupakan jumlah Edge, $\mathrm{N}$ merupakan jumlah Node, sedangkan $\mathrm{P}$ merupakan jumlah cabang, sehingga $\mathrm{V}(\mathrm{G})=1+1=2$. Kemudian didapatkan jalur proses seperti pada Tabel 5.

Tabel 5 Jalur proses panduan gizi seimbang

\begin{tabular}{|c|c|l|}
\hline Jalur & Tahapan & \multicolumn{1}{|c|}{ Keterangan } \\
\hline 1 & $1-2-3-4-6-7-8$ & $\begin{array}{l}\text { Berhasil melakukan } \\
\text { panduan gizi seimbang }\end{array}$ \\
\hline 2 & 8 & $\begin{array}{l}\text { Berhasil melakukan } \\
\text { panduan gizi seimbang } \\
\text { namun disertai dengan } \\
\text { kemungkinan pengguna } \\
\text { lupa/terlewat mengisi } \\
\text { form data diri }\end{array}$ \\
\hline
\end{tabular}

Pengujian selanjutnya yaitu pada menu Kalkulator kalori. Setelah pengguna memilih menu tersebut, proses pertama yang dilakukan setelah menu dipilih adalah membuka layout kalkulator1 yang berisi instruksi penggunaan kalkulator kalori. Kemudian pengguna dapat memilih tombol Hitung kalori yang akan menampilkan layout kalkulator2 yang berisi daftar makanan. Setelah memilih daftar makanan serta jumlahnya, pengguna dapat memilih tombol Lanjutkan ke hasil yang berisi hasil perhitungan kalori dari daftar makanan yang dipilih sebelumnya. Pada halaman ini pengguna dapat memilih tombol Kembali ke menu awal untuk kembali ke Halaman Beranda (layout Home). Pada Gambar 31 ditunjukkan Flowgraph dari proses kalkulator kalori.

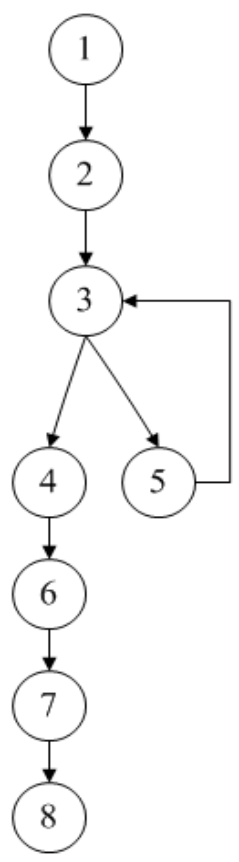

Gambar 31. Flowgraph proses kalkulator kalori

Dari Flowgraph pada Gambar 31 didapatkan nilai kompleksitas cyclomatic $\mathrm{V}(\mathrm{G})=\mathrm{E}-\mathrm{N}+2$ atau $\mathrm{V}(\mathrm{G})=\mathrm{P}+1$, dimana $\mathrm{E}$ merupakan jumlah Edge, $\mathrm{N}$ merupakan jumlah Node, sedangkan $\mathrm{P}$ merupakan jumlah cabang, sehingga $\mathrm{V}(\mathrm{G})=1+1=2$. Kemudian didapatkan jalur proses seperti pada Tabel 6.

Tabel 6 Jalur proses kalkulator kalori

\begin{tabular}{|c|l|l|}
\hline Jalur & \multicolumn{1}{|c|}{ Tahapan } & \multicolumn{1}{|c|}{ Keterangan } \\
\hline 1 & $1-2-3-4-6-7-8$ & $\begin{array}{l}\text { Berhasil menghitung } \\
\text { total kalori dari daftar } \\
\text { makanan yang dipilih } \\
\text { pengguna }\end{array}$ \\
\hline \multirow{2}{*}{} & $1-2-3-5-3-4-6-7-8$ & $\begin{array}{l}\text { Berhasil menghitung } \\
\text { total kalori dari daftar } \\
\text { makanan yang dipilih } \\
\text { pengguna dengan } \\
\text { kemungkinan daftar } \\
\text { makanan tidak dipilih } \\
\text { sama sekali atau porsi } \\
\text { makanan yang tidak } \\
\text { diisi. }\end{array}$ \\
\hline
\end{tabular}

\section{Tahap Pengujian Mesin Inferensi}

Tahap pengujian mesin inferensi merupakan tahapan untuk menguji metode yang digunakan oleh sistem dalam mencari solusi dari sebuah masalah. Pengujian ini dilakukan untuk menguji penggunaan metode backward chaining pada pengembangan aplikasi.. Pada Tabel 7 merupakan hasil dari pengujian metode backward chaining.

Tabel 7 Hasil pengujian metode backward chaining

\begin{tabular}{|c|l|l|}
\hline No & \multicolumn{1}{|c|}{$\begin{array}{c}\text { Metode Backward } \\
\text { Chaining }\end{array}$} & \multicolumn{1}{|c|}{ Penerapan pada aplikasi } \\
\hline 1 & Menentukan hipotesa & $\begin{array}{l}\text { Hipotesa : Kondisi Tubuh } \\
\text { menurut pengguna }\end{array}$ \\
\hline 2 & $\begin{array}{l}\text { Mengambil informasi } \\
\text { untuk mencari fakta }\end{array}$ & $\begin{array}{l}\text { Mengambil informasi } \\
\text { kondisi tubuh menurut } \\
\text { indeks masa tubuh }\end{array}$ \\
\hline
\end{tabular}




\begin{tabular}{|c|l|l|}
\hline & & $\begin{array}{l}\text { pengguna yang berasal dari } \\
\text { berat badan dan tinggi } \\
\text { badan. }\end{array}$ \\
\hline 3 & $\begin{array}{l}\text { Membandingkan nilai } \\
\text { antara hipotesa dengan } \\
\text { informasi } \\
\text { didapatkan }\end{array}$ & $\begin{array}{l}\text { Membandingkan antara } \\
\text { kondisi tubuh menurut } \\
\text { pengguna dengan indeks } \\
\text { masa tubuh. }\end{array}$ \\
\hline 4 & Mengambil keputusan & $\begin{array}{l}\text { Jika kondisi tubuh } \\
\text { menurut pengguna sama } \\
\text { dengan kondisi tubuh } \\
\text { menurut indeks masa } \\
\text { tubuh maka hipotesa } \\
\text { sesuai dengan fakta } \\
\text { Jika kondisi tubuh } \\
\text { menurut pengguna tidak } \\
\text { sama dengan kondisi } \\
\text { tubuh menurut indeks } \\
\text { masa tubuh maka hipotesa } \\
\text { tidak sesuai dengan fakta. }\end{array}$ \\
\hline
\end{tabular}

\section{Tahap Pengujian Akurasi}

Tahap pengujian akurasi merupakan tahapan untuk menguji keakuratannya dari sistem pakar untuk memberikan hasil identifikasi kesimpulan dari kondisi tubuh pengguna melalui informasi yang diberikan. Pengujian ini dilakukan untuk menguji setiap kondisi yang ada pada aplikasi dapat berjalan sesuai dengan tujuan atau tidak. Pada halaman lampiran merupakan tabel pengujian akurasi hasil kondisi tubuh. Dapat disimpulkan bahwa akurasi aplikasi panduan gizi seimbang berdasarkan 25 data kondisi tubuh yang telah diuji mempunyai tingkat akurasi yang sesuai dengan hasil analisa pakar dimana nilai akurasi $=$ (jumlah data akurat)/(jumlah seluruh data)x $100 \%$. Sehingga didapat nilai $25 / 25 \times 100 \%=100 \%$.

\section{KESIMPULAN DAN SARAN}

\section{A. Kesimpulan}

Dari hasil pengujian dan analisis aplikasi Panduan Gizi Seimbang berbasis Android ini dapat disimpulkan hal-hal sebagai berikut:

1. Berdasarkan hasil pengujian mesin inferensi menunjukkan bahwa aplikasi menggunakan backward chaining sebagai mesin inferensi sesuai dengan tujuan penelitian.

2. Berdasarkan hasil pengujian aplikasi menggunakan Whitebox, menunjukkan bahwa aplikasi sudah dapat berjalan sesuai dengan spesifikasi kebutuhan yang menampilkan hasil uji pada tiap fungsi aplikasi.

3. Aplikasi ini telah diuji dan diperiksa kebenaran data yang terdapat didalamnya oleh ahli gizi pada keakuratan dalam memberikan informasi menunjukkan bahwa aplikasi dapat digunakan dalam menghitung kalori yang dibutuhkan sehari-hari serta kondisi tubuh pengguna.

B. Saran

Saran yang diberikan dalam upaya pengembangan aplikasi yang lebih baik di kemudian hari:

1. Perlu dilakukan penelitian untuk penambahan fitur atur pola makan beserta fitur rekap data untuk mencatat makanan yang telah dikonsumsi agar bisa dijadikan acuan dalam berkonsultasi dengan ahli gizi.

2. Perlu dilakukan penelitian untuk penambahan data makanan pada kalkulator kalori agar bisa mencakup hampir semua makanan yang biasa dikonsumsi oleh pengguna.

\section{DAFTAR PUSTAKA}

[1] A.S Rosa., and Shalahudin, M, Rekayasa Perangkat Lunak Terstruktur dan Berorientasi Objek, Penerbit Informatika, September 2015.

[2] Garniardi, M.A., M. Afrina, and H. Novianti, "Rancang Bangun Perangkat Lunak Sistem Informasi Laboratorium Fasilkom Unsri”, J. Ilm. Generic, vol. 4, no. 1, pp. 21-32, 2009.

[3] Harris, J.A., Benedict. F.G., "A Biometric Study of Basal Metabolism", Proceedings of the National Academy of Sciences, Vol. 4, No. 12, Desember 1918.

[4] Hidayat, R., Status Gizi dan Angka Metabolisme Basal (AMB) Siswa Kelas IV, V, dan VI Sekolah Dasar Negeri Margoagung Seyegan Sleman, Skripsi S-1, Universitas Negeri Yogyakarta, 2015.

[5] Ignizio, J.P., Introduction To Expert System : The Development and Implementation Of Rule-Based Expert Systems, McGraw-Hill, Inc, 1991.

[6] Sommerville, Ian., Software Engineering, 9th ed., Pearson Education, Inc., Boston, 2010.

[7] Suprianto, D., Pemrograman Aplikasi Android, MediaKom, Yogyakarta, 2012.

[8] Susanto, J.A., Rancang Bangun Aplikasi Penilaian Status Gizi dan Penentuan Menu Makanan, Skripsi S-1, Sekolah Tinggi Manajemen Komputer \& Teknik Komputer Surabaya, 2015.

[9] Sutardjo, Susirah., Penuntun Diet Edisi Baru, chapter 2., Penerbit PT Gramedia Pustaka Utama, Jakarta, 2005.

[10] Yunanto, Wawan. "Algoritma Backward Chaining pada Rule-Based Expert System”, Komunitas eLearning IlmuKomputer.com, 2007. 


\section{Lampiran}

Tabel Pengujian Akurasi Kondisi Tubuh

\begin{tabular}{|c|c|c|c|c|c|}
\hline No & Kondisi Tubuh & $\begin{array}{l}\text { Jawaban } \\
\text { Pengguna }\end{array}$ & $\begin{array}{l}\text { Hasil Analisa } \\
\text { Sistem }\end{array}$ & $\begin{array}{l}\text { Hasil Analisa } \\
\text { Pakar }\end{array}$ & $\begin{array}{l}\text { Akurasi Hasil } \\
\text { Perbandingan }\end{array}$ \\
\hline 1 & $\mathrm{IMT}<17,0$ & $\begin{array}{l}\text { Sangat } \\
\text { Kurus }\end{array}$ & $\begin{array}{l}\text { Benar, kondisi } \\
\text { Sangat Kurus. } \\
\text { Jumlah Kalori + } \\
500 \text { kkal }\end{array}$ & $\begin{array}{l}\text { Benar, kondisi } \\
\text { Sangat Kurus. } \\
\text { Jumlah Kalori + } \\
500 \text { kkal }\end{array}$ & 1 \\
\hline 2 & IMT $<17,0$ & Kurus & $\begin{array}{l}\text { Salah, kondisi } \\
\text { Sangat Kurus. } \\
\text { Jumlah Kalori + } \\
500 \text { kkal }\end{array}$ & $\begin{array}{l}\text { Salah, kondisi } \\
\text { Sangat Kurus. } \\
\text { Jumlah Kalori + } \\
500 \text { kkal }\end{array}$ & 1 \\
\hline 3 & $\mathrm{IMT}<17,0$ & Normal & $\begin{array}{l}\text { Salah, kondisi } \\
\text { Sangat Kurus. } \\
\text { Jumlah Kalori + } \\
500 \mathrm{kkal}\end{array}$ & $\begin{array}{l}\text { Salah, kondisi } \\
\text { Sangat Kurus. } \\
\text { Jumlah Kalori + } \\
500 \mathrm{kkal}\end{array}$ & 1 \\
\hline 4 & IMT $<17,0$ & Gemuk & $\begin{array}{l}\text { Salah, kondisi } \\
\text { Sangat Kurus. } \\
\text { Jumlah Kalori + } \\
500 \mathrm{kkal}\end{array}$ & $\begin{array}{l}\text { Salah, kondisi } \\
\text { Sangat Kurus. } \\
\text { Jumlah Kalori + } \\
500 \text { kkal }\end{array}$ & 1 \\
\hline 5 & IMT $<17,0$ & $\begin{array}{l}\text { Sangat } \\
\text { Gemuk }\end{array}$ & $\begin{array}{l}\text { Salah, kondisi } \\
\text { Sangat Kurus. } \\
\text { Jumlah Kalori + } \\
500 \mathrm{kkal}\end{array}$ & $\begin{array}{l}\text { Salah, kondisi } \\
\text { Sangat Kurus. } \\
\text { Jumlah Kalori + } \\
500 \text { kkal }\end{array}$ & 1 \\
\hline 6 & $\begin{array}{l}\text { IMT } 17,0- \\
18,5\end{array}$ & $\begin{array}{l}\text { Sangat } \\
\text { Kurus }\end{array}$ & $\begin{array}{l}\text { Salah, kondisi } \\
\text { Kurus. Jumlah } \\
\text { Kalori }+500 \\
\text { kkal }\end{array}$ & $\begin{array}{l}\text { Salah, kondisi } \\
\text { Kurus. Jumlah } \\
\text { Kalori }+500 \text { kkal }\end{array}$ & 1 \\
\hline 7 & $\begin{array}{l}\text { IMT } 17,0- \\
18,5\end{array}$ & Kurus & $\begin{array}{l}\text { Benar, kondisi } \\
\text { Kurus. Jumlah } \\
\text { Kalori }+500 \\
\text { kkal }\end{array}$ & $\begin{array}{l}\text { Benar, kondisi } \\
\text { Kurus. Jumlah } \\
\text { Kalori }+500 \text { kkal }\end{array}$ & 1 \\
\hline 8 & $\begin{array}{l}\text { IMT } 17,0 \text { - } \\
18,5\end{array}$ & Normal & $\begin{array}{l}\text { Salah, kondisi } \\
\text { Kurus. Jumlah } \\
\text { Kalori }+500 \\
\text { kkal }\end{array}$ & $\begin{array}{l}\text { Salah, kondisi } \\
\text { Kurus. Jumlah } \\
\text { Kalori }+500 \text { kkal }\end{array}$ & 1 \\
\hline 9 & $\begin{array}{l}\text { IMT } 17,0 \text { - } \\
18,5\end{array}$ & Gemuk & $\begin{array}{l}\text { Salah, kondisi } \\
\text { Kurus. Jumlah } \\
\text { Kalori }+500 \\
\text { kkal }\end{array}$ & $\begin{array}{l}\text { Salah, kondisi } \\
\text { Kurus. Jumlah } \\
\text { Kalori }+500 \text { kkal }\end{array}$ & 1 \\
\hline 10 & $\begin{array}{l}\text { IMT } 17,0- \\
18,5\end{array}$ & $\begin{array}{l}\text { Sangat } \\
\text { Gemuk }\end{array}$ & $\begin{array}{l}\text { Salah, kondisi } \\
\text { Kurus. Jumlah } \\
\text { Kalori }+500 \\
\text { kkal }\end{array}$ & $\begin{array}{l}\text { Salah, kondisi } \\
\text { Kurus. Jumlah } \\
\text { Kalori }+500 \text { kkal }\end{array}$ & 1 \\
\hline 11 & $\begin{array}{l}\text { IMT }>18,5- \\
25,0\end{array}$ & $\begin{array}{l}\text { Sangat } \\
\text { Kurus }\end{array}$ & $\begin{array}{l}\text { Salah, kondisi } \\
\text { Normal }\end{array}$ & $\begin{array}{l}\text { Salah, kondisi } \\
\text { Normal }\end{array}$ & 1 \\
\hline 12 & $\begin{array}{l}\text { IMT }>18,5- \\
25,0\end{array}$ & Kurus & $\begin{array}{l}\text { Salah, kondisi } \\
\text { Normal }\end{array}$ & $\begin{array}{l}\text { Salah, kondisi } \\
\text { Normal }\end{array}$ & 1 \\
\hline 13 & $\begin{array}{l}\text { IMT }>18,5- \\
25,0\end{array}$ & Normal & $\begin{array}{l}\text { Benar, kondisi } \\
\text { Normal }\end{array}$ & $\begin{array}{l}\text { Benar, kondisi } \\
\text { Normal }\end{array}$ & 1 \\
\hline 14 & $\begin{array}{l}\text { IMT }>18,5- \\
25,0\end{array}$ & Gemuk & $\begin{array}{l}\text { Salah, kondisi } \\
\text { Normal }\end{array}$ & $\begin{array}{l}\text { Salah, kondisi } \\
\text { Normal }\end{array}$ & 1 \\
\hline 15 & $\begin{array}{l}\text { IMT }>18,5- \\
25,0\end{array}$ & $\begin{array}{l}\text { Sangat } \\
\text { Gemuk }\end{array}$ & $\begin{array}{l}\text { Salah, kondisi } \\
\text { Normal }\end{array}$ & $\begin{array}{l}\text { Salah, kondisi } \\
\text { Normal }\end{array}$ & 1 \\
\hline
\end{tabular}




\begin{tabular}{|c|c|c|c|c|c|}
\hline 16 & $\begin{array}{l}\text { IMT }>25,0- \\
27,0\end{array}$ & $\begin{array}{l}\text { Sangat } \\
\text { Kurus }\end{array}$ & $\begin{array}{l}\text { Salah, kondisi } \\
\text { Gemuk. Jumlah } \\
\text { Kalori - } 500 \text { kkal }\end{array}$ & $\begin{array}{l}\text { Salah, kondisi } \\
\text { Gemuk. Jumlah } \\
\text { Kalori - } 500 \text { kkal }\end{array}$ & 1 \\
\hline 17 & $\begin{array}{l}\text { IMT }>25,0- \\
27,0\end{array}$ & Kurus & $\begin{array}{l}\text { Salah, kondisi } \\
\text { Gemuk. Jumlah } \\
\text { Kalori - } 500 \text { kkal }\end{array}$ & $\begin{array}{l}\text { Salah, kondisi } \\
\text { Gemuk. Jumlah } \\
\text { Kalori - } 500 \text { kkal }\end{array}$ & 1 \\
\hline 18 & $\begin{array}{l}\text { IMT }>25,0- \\
27,0\end{array}$ & Normal & $\begin{array}{l}\text { Salah, kondisi } \\
\text { Gemuk. Jumlah } \\
\text { Kalori - } 500 \text { kkal }\end{array}$ & $\begin{array}{l}\text { Salah, kondisi } \\
\text { Gemuk. Jumlah } \\
\text { Kalori - } 500 \text { kkal }\end{array}$ & 1 \\
\hline 19 & $\begin{array}{l}\text { IMT }>25,0- \\
27,0\end{array}$ & Gemuk & $\begin{array}{l}\text { Benar, kondisi } \\
\text { Gemuk. Jumlah } \\
\text { Kalori - } 500 \text { kkal }\end{array}$ & $\begin{array}{l}\text { Benar, kondisi } \\
\text { Gemuk. Jumlah } \\
\text { Kalori - } 500 \text { kkal }\end{array}$ & 1 \\
\hline 20 & $\begin{array}{l}\text { IMT }>25,0- \\
27,0\end{array}$ & $\begin{array}{l}\text { Sangat } \\
\text { Gemuk }\end{array}$ & $\begin{array}{l}\text { Salah, kondisi } \\
\text { Gemuk. Jumlah } \\
\text { Kalori - } 500 \text { kkal }\end{array}$ & $\begin{array}{l}\text { Salah, kondisi } \\
\text { Gemuk. Jumlah } \\
\text { Kalori - } 500 \text { kkal }\end{array}$ & 1 \\
\hline 21 & IMT $>27,0$ & $\begin{array}{l}\text { Sangat } \\
\text { Kurus }\end{array}$ & $\begin{array}{l}\text { Salah, kondisi } \\
\text { Sangat Gemuk. } \\
\text { Jumlah kalori - } \\
500 \text { kkal }\end{array}$ & $\begin{array}{l}\text { Salah, kondisi } \\
\text { Sangat Gemuk. } \\
\text { Jumlah kalori - } \\
500 \text { kkal }\end{array}$ & 1 \\
\hline 22 & IMT $>27,0$ & Kurus & $\begin{array}{l}\text { Salah, kondisi } \\
\text { Sangat Gemuk. } \\
\text { Jumlah kalori - } \\
500 \text { kkal }\end{array}$ & $\begin{array}{l}\text { Salah, kondisi } \\
\text { Sangat Gemuk. } \\
\text { Jumlah kalori - } \\
500 \text { kkal }\end{array}$ & 1 \\
\hline 23 & IMT $>27,0$ & Normal & $\begin{array}{l}\text { Salah, kondisi } \\
\text { Sangat Gemuk. } \\
\text { Jumlah kalori - } \\
500 \text { kkal }\end{array}$ & $\begin{array}{l}\text { Salah, kondisi } \\
\text { Sangat Gemuk. } \\
\text { Jumlah kalori - } \\
500 \text { kkal }\end{array}$ & 1 \\
\hline 24 & IMT $>27,0$ & Gemuk & $\begin{array}{l}\text { Salah, kondisi } \\
\text { Sangat Gemuk. } \\
\text { Jumlah kalori - } \\
500 \text { kkal }\end{array}$ & $\begin{array}{l}\text { Salah, kondisi } \\
\text { Sangat Gemuk. } \\
\text { Jumlah kalori - } \\
500 \text { kkal }\end{array}$ & 1 \\
\hline 25 & IMT $>27,0$ & $\begin{array}{l}\text { Sangat } \\
\text { Gemuk }\end{array}$ & $\begin{array}{l}\text { Benar, kondisi } \\
\text { Sangat Gemuk. } \\
\text { Jumlah kalori - } \\
500 \text { kkal }\end{array}$ & $\begin{array}{l}\text { Benar, kondisi } \\
\text { Sangat Gemuk. } \\
\text { Jumlah kalori - } \\
500 \text { kkal }\end{array}$ & 1 \\
\hline
\end{tabular}

